\title{
Two new species of Apistogramma Regan (Teleostei: Cichlidae) from the rio Trombetas, Pará State, Brazil
}

\author{
Sven O Kullander* and Efrem J. G. Ferreira**
}

Apistogramma angayuara is described from the rio Trombetas close to the cachoeira Vira Mundo where it is found in association with rapids. It is assigned to the $A$. pertensis species group, distinguished by the following characters in combination: three prominent stripes composed of dark spots along the sides of the abdomen, 2 vs. 3 postlachrymal infraorbital pores, $5 \mathrm{vs} .4$ dentary pores, low dorsal fin in adult males, and presence of a caudal spot. It is the smallest species of Apistogramma reported so far, with the largest male $24.7 \mathrm{~mm} \mathrm{SL}$ and the largest female $22.7 \mathrm{~mm} \mathrm{SL}$, and the first cichlid species found with a significant proportion of rhizopods in the stomach content. Apistogramma salpinction is described from lentic habitats at the margin of road BR-163, circa $70 \mathrm{~km}$ from Cachoeira Porteira village, in a swamp most probably connected to the igarapé Caxipacoré. It is compared to members of the Apistogramma cacatuoides group with which it shares prolonged anterior dorsal fin lappets and marginal caudal fin streamers in adult males. It is distinguished from all other species of Apistogramma by the color pattern which includes a lateral band and abdominal stripes that become darker and have much lighter interspaces on the caudal peduncle, and a caudal spot that is divided into elongated blotches continuing the lateral band and upper two abdominal stripes, respectively.

Apistogramma angayuara é descrita para o rio Trombetas próximo à cachoeira Vira Mundo, onde é encontrada associada com corredeiras. É a menor espécie de Apistogramma até agora registrada, com o maior macho atingindo $24,7 \mathrm{~mm} \mathrm{CP}$, e a maior fêmea $22,7 \mathrm{~mm}$ CP. Trata-se do primeiro registro de uma espécie de ciclideo com grande quantidade de rizopodos em seu conteúdo estomacal. Apistogramma angayuara pertence ao grupo A. pertensis e difere das demais espécies deste grupo pela seguinte combinação de caracteres: três conspícuas séries de pontos escuros ao longo da região abdominal, 2 vs. 3 poros infra-orbitais pós-lacrimais, e $5 v s .4$ poros dentários, nadadeira dorsal baixa em machos adultos, e presença de uma mancha caudal grande. Apistogramma salpinction é descrita de habitats lênticos localizados na margem da BR-163, cerca de $70 \mathrm{~km}$ da vila de Cachoeira Porteira, em um alagadiço que provavelmente está conectado ao igarapé Caxipacoré, e é semelhante a membros do grupo Apistogramma cacatuoides com o qual compartilha as membranas anteriores da nadadeira dorsal prolongadas e faixas marginais na nadadeira caudal em machos adultos. Entretanto, difere pelo padrão de colorido que inclui uma faixa lateral e listras abdominais mais escuras e com interespaços mais claros no pedúnculo caudal, que se prolongam sobre a base da nadadeira caudal em uma pinta caudal dividida em manchas alongadas continuando a faixa lateral e duas listras abdominais, respectivamente.

Key words: Amazonia, fish, microphagy, Neotropical, rheophily, taxonomy.

\section{Introduction}

The South American cichlid genus Apistogramma Regan is one of the most species rich genera of cichlids, with over 60 valid species and many undescribed species recognized (Kullander, 2003). Still, there are very few records of this ge- nus from the major Amazon tributaries of the Brazilian and Guianas highlands, and then mainly from downstream of the first falls or rapids. Our unpublished observations suggest that the clearwater rivers of eastern Amazonia, such as the Tapajós, Xingu, Tocantins, and Trombetas, are indeed poor in species of Apistogramma compared to the Western Ama-

\footnotetext{
* Department of Vertebrate Zoology, Swedish Museum of Natural History, PO Box 50007, SE-104 05 Stockholm, Sweden. e-mail: sven.kullander@nrm.se

** Coordenação de Pesquisas em Biologia Aquática, INPA, CP 478, 69083-000 Manaus, AM, Brazil. e-mail: efrem@inpa.gov.br
} 
zon lowlands or the rio Negro. Nevertheless, the genus seems to be represented by at least one or more endemic species in each of those rivers.

The major rapids in the lower rio Trombetas, the cachoeira Porteira and cachoeira Vira Mundo, were projected as the future site of a hydroelectric power plant and the junior author made an extensive inventory of the ichthyofauna in and near those rapids in 1985-1988 (Ferreira, 1993). A total of 342 species were recorded, making the Trombetas one of the most species rich rivers in South America. Four species of Apistogramma were collected. Among them, one species is similar to A. hippolytae Kullander, but appears to be undescribed and is being worked on in the context of a comparison with several similar species from various Amazonian blackwaters. A second species collected was A. pertensis (Haseman), which is reported from numerous localities in the Amazon basin, and which is found in the rio Trombetas only downstream from the cachoeira Porteira.

The remaining two species, selected for description in this paper, are distinctive species that may very well be restricted to the rio Trombetas upstream from the lower rapids. One of them is the first rheophilic Apistogramma to be described, and also is the first cichlid known to feed mainly on protozoans.

\section{Material and Methods}

Measurements and counts were taken as described by Kullander $(1980,1986)$. Specimen lengths are given as standard length (SL). Scale rows are numbered as described by Kullander (1990), i.e., the horizontal row including the lower lateral line is designated as row 0 , and the rows are counted as E1, E2, E3, etc., dorsally, and as H1, H2, H3, etc., ventrally. Counts of external openings of the infraorbital lateralis canal refer to the postlachrymal number, i.e., excluding the opening shared by the posterior lachrymal lateralis foramen and the anterior foramen of the first infraorbital bone. Color marking terminology follows Kullander $(1980,1986)$. Vertebral counts include the last halfcentrum and were taken from X-radiographs made on Agfa Structurix D2 plates with a Philips MG105 low voltage $\mathrm{X}$-ray unit. Drawings were made using a drawing tube fitted to a Wild M5A stereomicroscope.

Institutional abbreviations: INPA, Instituto Nacional de Pesquisas da Amazônia, Manaus; MCNG, Museu de Ciencias Naturales, Guanare; NRM, Swedish Museum of Natural History, Stockholm; SMF, Naturmuseum Senckenberg, Frankfurt/ Main; USNM, National Museum of Natural History, Smithsonian Institution, Washington, DC.

Comparative materials. Apistogramma arua Römer \& Warzel: Brazil: Pará: rio Tapajós drainage: rio Aruá: NRM 41188, 1, 45.3 mm SL; Aquarium: NRM 41190, 5, 31.4-38.8 mm SL. Apistogramma geisleri Meinken: Brazil: Pará: rio Trombetas drainage: NRM 17794, 3, 23.1-30.4 mm SL, Road Alenquer-Óbidos; NRM 19498, 7, 11.8-19.1 mm SL, lago de Sapucuá, Cabeceira Cururi ca 5-7 km upstream of Oriximiná; SMF 10617, holotype,
28.2 mm SL, Óbidos, rio Curuçamba; SMF 10618-10619, 2 paratypes, 20.9-25.3 mm SL, Óbidos, rio Curuçamba. Apistogramma gephyra Kullander: Brazil: Amazonas: rio Negro drainage: NRM 40641,1, $48.9 \mathrm{~mm}$ SL, about $15 \mathrm{~km}$ downstream of Novo Caiae, comunidade Bacaba. Apistogramma sp. aff. hippolytae: Brazil: Pará: rio Trombetas drainage: INPA 24054, 3, 26.5-28.7 mm SL, swamp on BR-163, Km 70; INPA 24055, 2, 24.7-26.9 mm SL, below cachoeira Vira Mundo; INPA 24056, 1, 26.4 mm SL, swamp on BR-163, Km 70. Apistogramma iniridae Kullander: Colombia: Guainía: río Inirida drainage: NRM 17799, 1, $28.0 \mathrm{~mm}$ SL, caño Caimán, small river and flooded areas, $3^{\circ} 30^{\prime \prime} \mathrm{N}$ 680'W; NRM 18753, 21, 19.8-36.0 mm SL, Puerto Inírida area, pond at caño Bocón; NRM 26210, 1, 31.8 mm SL, caño Carbón, Cuayare, $3^{\circ} 56^{\prime} \mathrm{N} 67^{\circ} 50^{\prime} \mathrm{W}$; NRM 26220, 11, 22.0-30.6 mm SL, caño Bocón, savannita (probably near Yurí), $3^{\circ} 38^{\prime} \mathrm{N} 68^{\circ} 11^{\prime} \mathrm{W}$. Apistogramma inornata Staeck: Venezuela: río Orinoco drainage: MCNG 31938, 1, 21.9 mm SL, Guárico, Parque Nacional AguaroGuariquito, at bridge, small tributary of the río Aguaro, $8^{\circ} 3^{\prime} 6^{\prime \prime} \mathrm{N}$ 66²5’34"W; USNM 232879, 4, 15.7-21.4 mm SL, Monagas, río Orinoco, Barrancas, laguna El Guatero, 143 nautical miles upstream of sea buoy, $8^{\circ} 43^{\prime} \mathrm{N} 52^{\circ} 11^{\prime} \mathrm{W}$; USNM 232918, 6, 13.3$22.1 \mathrm{~mm}$ SL, Monagas, río Orinoco, Barrancas, laguna El Guatero, 143 nautical miles upstream of sea buoy, $8^{\circ} 41^{\prime} \mathrm{N} 62^{\circ} 11^{\prime} \mathrm{W}$. Apistogramma meinkeni Kullander: Brazil: Amazonas: rio Uaupés drainage: NRM 19630, 2, 27.0-31.1 mm SL, igarapé de Panela, left bank tributary to rio Uaupés near Cunuri, a few km upstream from Trovao. Apistogramma pertensis: Brazil: Pará: rio Trombetas drainage: INPA 14372, 8, 12.5-32.4 mm SL, cachoeira Porteira; NRM 16472, 5, 13.5-29.6 mm SL, cachoeira Porteira; NRM 41419, 1, $37.6 \mathrm{~mm}$ SL, upstream of Oriximiná, lago Caipuru; NRM 46461, 24, 15.4-29.2 mm SL, rio Trombetas right side upstream of Porto Trombetas, igarapé de Mora; rio Tapajós drainage: NRM 18516 , 1, 17.9 mm SL, Santarém, rio Tapajós shore opposite Santarém, peninsula, igarapé Açu; Amazonas: rio Tefé drainage: NRM 24022, 73, 15.8-26.7 mm SL, lagoa on right bank of rio Tefé, ca $130 \mathrm{~km}$ above Tefé, ca 100m long narrow 'canal' connected to river; NRM 41207, 1, 30.7 mm SL, rio Tefé; rio Negro drainage: NRM 29412, 1, $47.8 \mathrm{~mm} \mathrm{SL}$, rio Negro, paraná do Marauiá. Apistogramma pulchra Kullander: Brazil: Rondônia: rio Madeira drainage: NRM 40644, 1, 31,8 mm SL, rio Preto do Candeias near Porto Velho. Apistogramma uaupesi Kullander: Venezuela: Amazonas: río Negro drainage: NRM 19510, 28, 12.8-25.1 mm SL, caño Dap, upstream of Solano and downstream of caño Daciapo, $2^{\circ} 0^{\prime} 0^{\prime \prime} \mathrm{N}$ 66 57'0' 'W. Apistogramma velifera Staeck: Venezuela: río Orinoco drainage: Amazonas: MCNG 23641, 9, 20.9-37.3 mm SL, caño Pozo Azul at Balneario Pozo Azul, Puerto Ayacucho, 550’0" S 67²9'0" W; Ature: USNM 269308pt., 1, $21.1 \mathrm{~mm} \mathrm{SL}$, small drying backwater pool off road from El Burro to Puerto Ayacucho, 547'N 67²9'W; USNM 269358, 4, 17.1-27.7 mm SL, Balnearia Pozo Azul, approximately $1 \mathrm{~km}$ to east of Puerto Ayacucho to Solano road, approx. $30 \mathrm{~km} \mathrm{~N}$ of Puerto Ayacucho, $5^{\circ} 53^{\prime} \mathrm{N}$ $67^{\circ} 28^{\prime} \mathrm{W}$.

\section{Apistogramma angayuara, new species Figs. 1-4}

Holotype. INPA 24058. Adult male, $23.7 \mathrm{~mm}$ SL. Brazil, Estado do Pará, rio Trombetas right bank, stagnant pool with sand, rock and dry leaves, below cachoeira Vira Mundo. 4 October 1985. E. Ferreira \& L. Rapp Py-Daniel. 


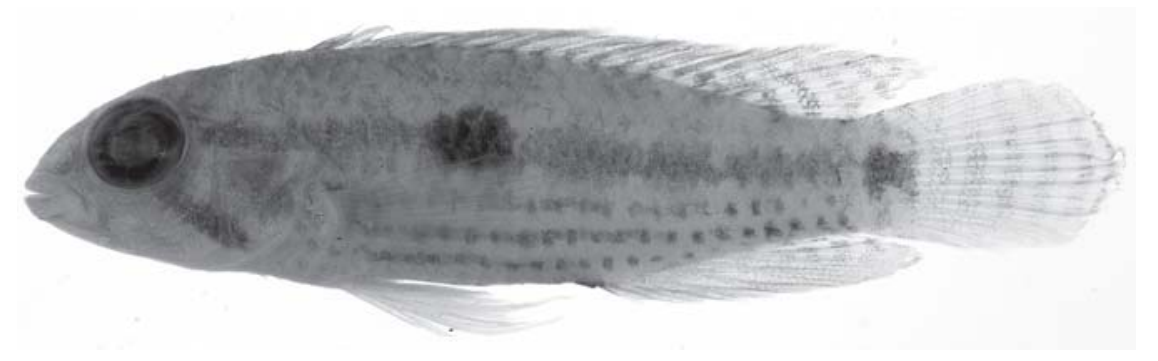

Fig. 1. Apistogramma angayuara, holotype, INPA 24058, adult male, $23.7 \mathrm{~mm}$ SL. Brazil, rio Trombetas below cachoeira Vira Mundo.

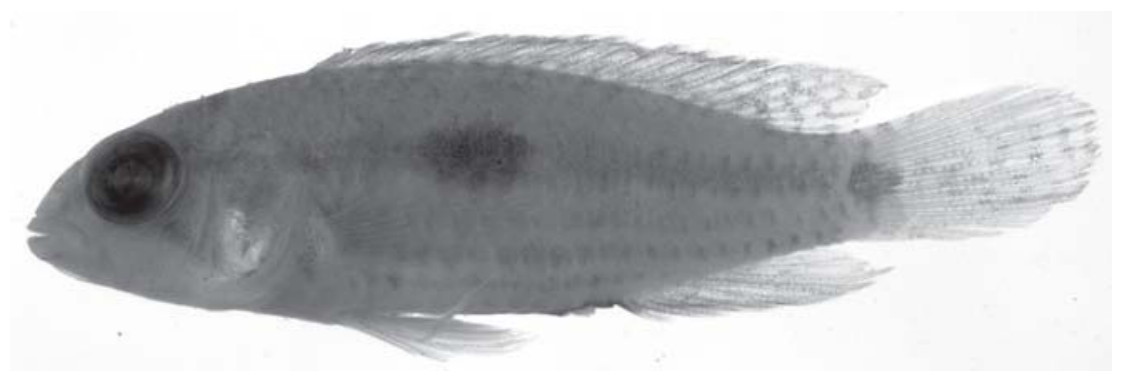

Fig. 2. Apistogramma angayuara, paratype, INPA 12647, female, $22.1 \mathrm{~mm}$ SL. Brazil, rio Trombetas below cachoeira Vira Mundo.

Paratypes. All from Brazil, Estado do Pará, rio Trombetas drainage. INPA 12645, 1 male, 22.6 mm, igarapé at Km 10 on BR-163, 7 Oct 1985, E. Ferreira \& L. Rapp Py-Daniel. INPA 12646, 1 juvenile, cachoeira Porteira, quiet water running above rocks, 10 Apr 1985, E. Ferreira \& M. Jégu. INPA 12647 (14) and NRM 37028(5), 8 males, 18.7-24.7 mm, 6 females 19.9-22.7 mm, and 5 juveniles or sex indeterminable, 12.6-15.6 mm SL, same data as holotype.

Diagnosis. An elongate (body depth $26.4-29.4 \%$ of SL) species of the $A$. pertensis species group, of small size $(<30 \mathrm{~mm}$ $\mathrm{SL}$ ), distinguished from other species of the $A$. pertensis group by fin shape, color pattern and number of infraorbital and dentary lateral line pores as follows: (1) presence of three horizontal rows of prominent dark spots along the abdominal sides $v s$. absence, except in A. velifera; (2) both sexes with low dorsal fin and rounded caudal fin $v s$. dorsal fin lappets prolonged and caudal fin elongately rounded or lanceolate in males of other species, except in A. pulchra, and dorsal fin low in males of $A$. gephyra; (3) 2 postlachrymal infraorbital lateralis pores vs. 3 in A. pertensis, A. meinkeni, and $A$. velifera; (4) 5 dentary lateralis pores vs. 4 in $A$. gephyra, $A$. meinkeni, and $A$. pulchra; (5) presence of a caudal spot $v s$. absence in $A$. iniridae and $A$. uaupesi.

Description. Based on holotype with comments on variation in other adults. See Table 1 for summary of morphometric data, and Figs. 1-2 for general aspect.

Elongate (body depth 26.4-29.4\% of SL), body almost uni- formly deep posterior to orbit. Snout short, with steeply inclined dorsal contour, less strongly sloping ventral contour. Maxilla extending to vertical from slightly posterior to anterior margin of orbit. Eye large, supralateral, its dorsal margin tangented by predorsal contour. Preopercle serrated in 3, supracleithrum in 6 of 10 measured specimens; no posttemporal serrations.

E1 row scales 21 (1), 22 (19). Cheek scaled only posterodorsally, where 1-2 horizontal scale rows developed (Fig. 3). Predorsal scales 8-10. Prepelvic area naked anterior to tips of cleithra; prepelvic scales 5-7. Scales in transverse row 9, of

Table 1. Morphometry of Apistogramma angayuara. Measurements expressed as percent of SL, except SL in mm; $\mathrm{n}=$ 10 (5 males, 5 females).

\begin{tabular}{lccccc}
\hline & Holotype & Min & Max & Mean & SD \\
\hline SL (mm) & 23.7 & 19.4 & 24.7 & 22.4 & \\
Head length & 32.1 & 30.8 & 32.9 & 31.8 & 0.67 \\
Snout length & 5.9 & 5.1 & 6.5 & 5.7 & 0.46 \\
Upper jaw length & 9.3 & 8.3 & 9.7 & 9.3 & 0.49 \\
Lower jaw length & 13.5 & 12.4 & 14.0 & 13.1 & 0.54 \\
Body depth & 27.4 & 26.4 & 29.4 & 27.9 & 1.09 \\
Orbital diameter & 13.5 & 11.9 & 13.6 & 13.1 & 0.63 \\
Head width & 15.6 & 15.6 & 16.5 & 16.0 & 0.29 \\
Interorbital width & 6.8 & 6.1 & 6.8 & 6.5 & 0.22 \\
Preorbital depth & 2.5 & 2.0 & 2.6 & 2.3 & 0.21 \\
Caudal peduncle depth & 13.9 & 12.7 & 14.4 & 13.5 & 0.57 \\
Caudal peduncle length & 14.3 & 13.1 & 15.7 & 14.0 & 0.82 \\
Pectoral fin length & 27.0 & 25.5 & 28.4 & 26.8 & 0.88 \\
Pelvic fin length & 27.4 & 22.9 & 27.4 & 24.8 & 1.57 \\
Last dorsal spine length & 14.8 & 14.8 & 16.7 & 15.6 & 0.61 \\
\hline
\end{tabular}




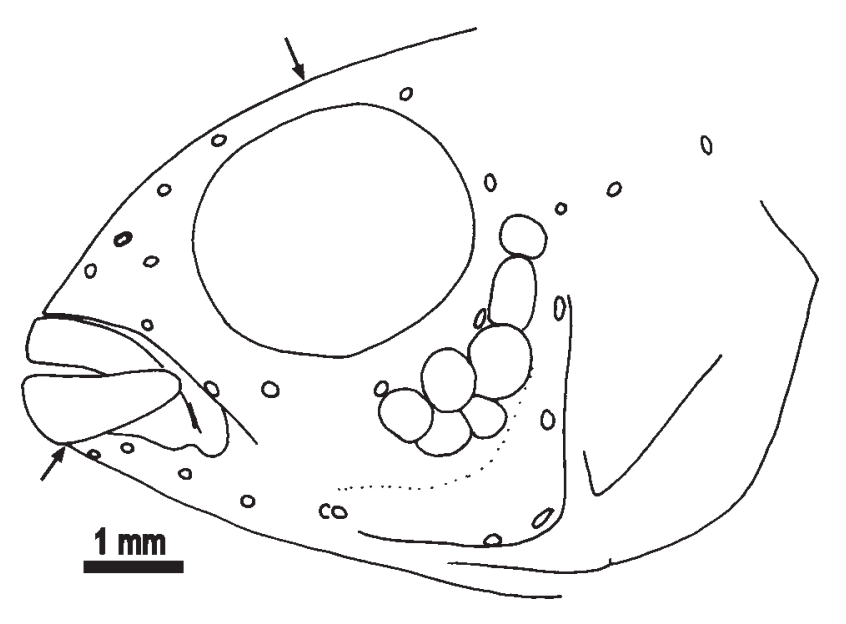

Fig. 3. Apistogramma angayuara, holotype, INPA 24058, 23.7 $\mathrm{mm}$ SL, pattern of lateralis openings on head. Arrows point to coronalis pore and anterior dentary pores hidden from view.

which 7 below upper lateral line. Circumpeduncular scale rows 16. Lateral line scales 13/5 (2), 14/7 (1), 15/5 (1), 15/6 (1), 16/6 (1), 16/7 (2); of which 8-11/0-4 bearing tubes. Scales between upper lateral line and dorsal fin 3 anteriorly, $1 / 2$ posteriorly. Fins naked except caudal fin, which scaled on basal $1 / 4$.

Lateral line canal system on head examined only in alcohol preserved specimens, but obviously a full set of canals and foramina is present, except for 2 instead of 3 postlachrymal pores (Fig. 3). Dentary with 5 pores; anguloarticular canal present, with anterior and posterior openings and corresponding skin pore, posterior pore separate from anteriormost preopercular pore, however in holotype posterior perforation of skin absent; 6 preopercular pores; coronalis pore present; nasal with pores at each end, posterior obviously shared with frontal canal; frontal with 4 pores; lachrymal bone narrow, with 4 pores; two narrow infraorbital ossicles, anterior with terminal openings, posterior with anterior terminal opening and posterior opening which is slightly anterior to termination of bone (as in Kullander, 1987: fig. 10c).

Dorsal fin low; soft part pointed and extending to about $1 / 3$ of caudal fin in adult males; soft part rounded, shorter, in adult females and young specimens. D. XV.6 (6), XV.7 (13), XVI.5 (1), XVI.6 (1). Soft anal fin pointed, reaching to about $1 /$ 3 of caudal fin in adult males, rounded and shorter in adult females and young specimens; A. III.5 (2), III.6 (19). Caudal fin rounded, with 3 procurrent and 8 principal rays in each lobe. Pelvic fin pointed, first ray slightly the longer, extending to about vent or first anal fin spine; no sexual dimorphism. Pectoral fin rounded, extending almost to vertical from vent; P. $11(10)$.

Jaw teeth caniniform, erect, very slightly curved; 17-21/ 18-23 in upper/lower jaw outer hemiseries. Outer row teeth slightly longer than inner row teeth. Outer row extending along entire jaw margin; one inner row in upper jaw, extending to middle of jaw; one or two inner rows in lower jaw, confined to anterior $1 / 3$ of jaw. Gill rakers externally on first gill arch, one in angle and 1(4), 2(5), 3(1) ceratobranchial; gill rakers on lower pharyngeal tooth-plate 7-9, but difficult to count owing to small size. Lower pharyngeal tooth-plate slightly wider than long (length $85 \%$ of width), deeply emarginate posteriorly; $15+15$ teeth in posterior row, 6 teeth in median row; most teeth in posteriormost row and larger median teeth of next anterior row tricuspid, shape changing to slender and unicuspid rostrally on bone.

Vertebrae $12+12=24$ (19) (count not possible in 2 due to deformities); whereby last abdominal vertebra actually articulating by a short haemal apophysis with first anal fin pterygiophore in 18 specimens. Hypurals $1-5$ separate in 19 specimens; hypurals $1+2$ and $3+4$ fused in one specimen and hypural $3+4$ fused in one specimen.

Color pattern in alcohol. Ground color yellowish white, back with diffuse background pigment pattern with some concentration at scale margins, chest and belly with sparse pigment. No vertical bars. Wide brownish lateral band from gill cleft to end of caudal peduncle, separated from caudal spot by narrow light zone; about one scale deep, margins uneven, chiefly running on scale rows 0 and E1. Dark brown, slightly elongate lateral spot covering E1 row scales 5-7 and half to 2/3 of scales below, and also reflected on adjacent scales above; rarely with slightly lighter marginal zones anteriorly and posteriorly.

Three prominent abdominal stripes composed of a round or deep oval dark brown spot at margin of each scale in rows H1-H3, interconnected horizontally by more or less strongly expressed pigment. Stripes mostly show as rows of dark welldefined spots, but in occasional individuals interspersed pigmentation is so strong that nearly uniform stripes are formed. Dark brown midventral stripe from between pelvic fin bases to base of first anal fin spine. Black spot dorsally and ventrally on axillary side of pectoral fin base.

No supraorbital stripe. Preorbital stripe not well defined in any specimen, but can often be traced in otherwise nearly uniform grayish dorsal snout region. Postorbital stripe brown, from orbit to lateral band. Dark brown suborbital stripe, of about same width as pupil diameter, extending caudoventral from between pores of second infraorbital bone across lower portion of vertical limb of preopercle and onto opercle, preopercle and subopercle in region where those bones meet. Dark brown spot at mandibular tip and adjacent intermandibular region, immediately behind lower lip fold. Snout grayish.

Dorsal fin with dark brown spot at base of each spine and ray, spinous portion smoky with hyaline lappet tips; in several specimens first interradial membrane dark brown, followed by dark brown submarginal stripe. Soft dorsal fin lighter, with 5 or 6 dark stripes across rays. Anal fin with grey lower margin, otherwise brownish, inwardly hyaline and with about 4 rows of dark spots across posterior membranes and rays. Caudal spot midbasal, dark brown, form about square; some pigment above and below spot; on caudal fin distal to caudal 


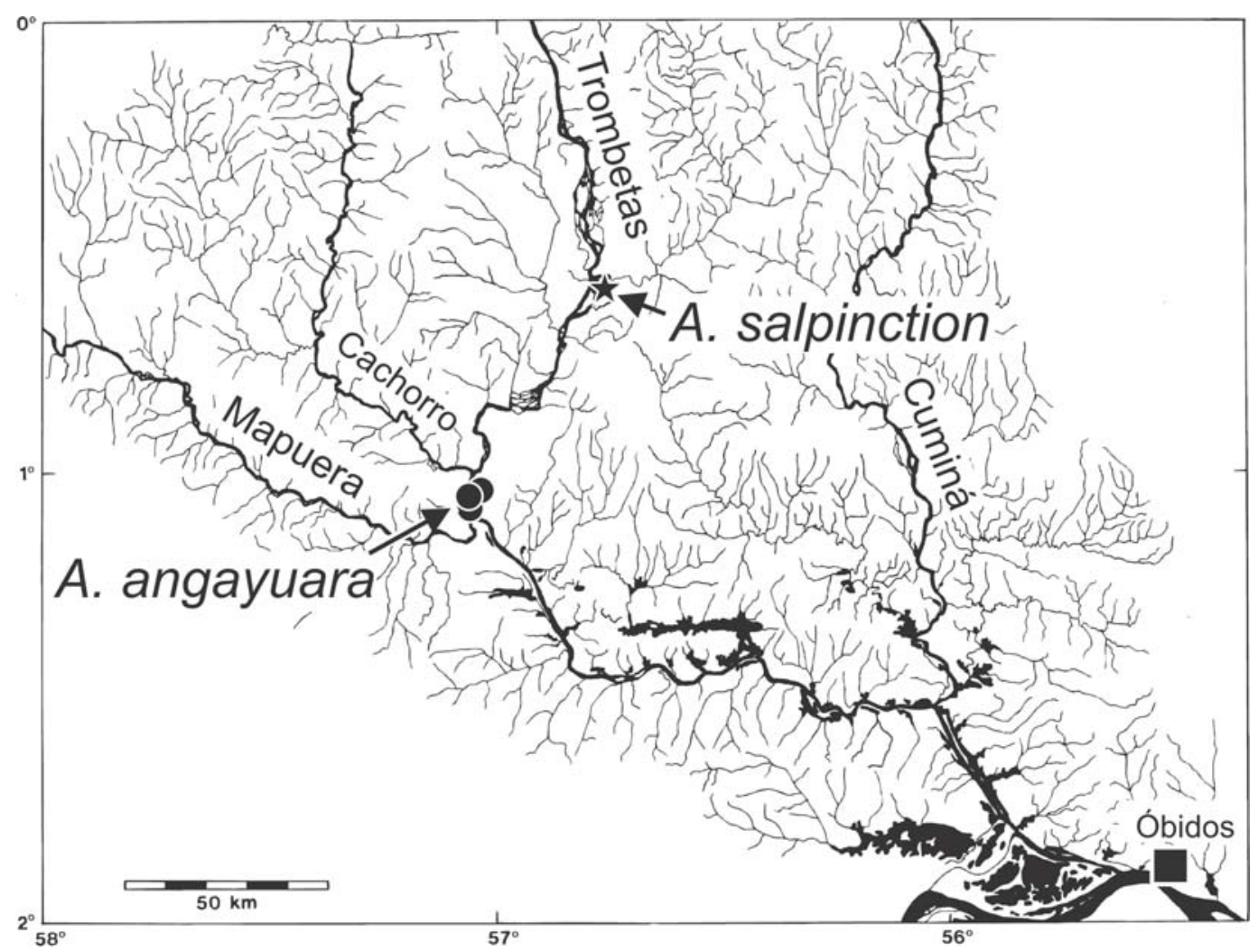

Fig. 4. Collecting sites of Apistogramma angayuara and A. salpinction plotted on a map of the lower rio Trombetas drainage.

spot six prominent vertical stripes, each stripe about as wide as interspace between stripes. Pelvic fins white or hyaline with only a few pigment spots basally.

Females differ from males in less intense fin pigmentation; soft dorsal anal and caudal fins with fewer and only indistinctly expressed vertical stripes or rows of spots. Pelvic fins white or hyaline also in females. Expression of the lateral spot variable between individuals, but a strongly expressed lateral spot may be more frequent in females.

Geographical distribution. Apistogramma angayuara has been collected in the rio Trombetas only in the region of cachoeira Porteira and cachoeira Vira Mundo (Fig. 4).

Ecology and habitats. The gut content analyses of five specimens $(19-24 \mathrm{~mm})$ from rapids showed that aquatic invertebrates were the most important food items consumed by this species. Rhizopods were the dominant item, followed by sponges and cladocerans. Both males and females dissected have well developed gonads.

Collecting at cachoeira Porteira was done in a channel where the Trombetas and Mapuera rivers meet, just above the first waterfall, most of it not deep, but with very fast running water. Lots of aquatic plants (Podostemonaceae) grow on the rocks. During the dry season most of the rocks are exposed, and many pools are formed where the fishes are trapped and easily collected with rotenone.

Collecting in the rio Trombetas downstream from the cachoeira Vira Mundo was done on the right bank, just below a channel that connects the river with its upper part during the rainy season. During the dry season this channel dries up, and lots of pools are formed on the banks and over the rocks in which lots of fishes are trapped and easily collected with rotenone.

The igarapé at $\mathrm{km} 10$ on BR-163 is a small clearwater forest stream crossing the road. It is only 1-3 meters wide and shallow, less than one meter deep. On the left side of the road there was a swamp formed by the damming of the stream. Many aquatic plants and algae were present and the water was running fast, but there were many protected places. This stream was destroyed by the logging activities.

Etymology. The species epithet, angayuara, refers to the slender shape of the species and is a Brazilian Lingua Geral adjective meaning skinny or thin (Grenand \& Ferreira, 1989). It is used here as a noun in apposition.

Relationships. Apistogramma angayuara conforms to the so-called $A$. pertensis group distinguished by Kullander (1980: 49) for A. pertensis, widely distributed in the Amazon basin, A. meinkeni, A. uaupesi, and A. gephyra from the rio Negro, $A$. iniridae from the upper río Orinoco, and $A$. pulchra from the rio Madeira drainage near Porto Velho. Staeck (2003) added A. inornata and A. velifera from the middle Orinoco drainage in Venezuela. Additional putatively distinct species or color forms are listed in aquarium literature (Koslowski, 2002; Staeck, 
2003), coming mainly from the Orinoco and Negro river basins.

The composition of the group remains provisional in the absence of a phylogenetic analysis, and the original diagnosis of Kullander (1980) has been invalidated by new information and new species described in the meantime. The chief original diagnostic character was the naked anterior chest, which is shared also with $A$. diplotaenia Kullander, a species of uncertain relationships (Kullander, 1987). In males of $A$. pertensis, A. iniridae, A. meinkeni, A. uaupesi, A. inornata, and A. velifera, but not in A. gephyra or A. pulchra, the dorsal fin lappets are prolonged well beyond the spine tips, and at least the posterior lappets are united beyond the spine tips. A similar high dorsal fin with the fin membrane continued beyond spine tips is found in large males of $A$. borellii (Regan), a species of uncertain relationships. The caudal fin is rounded to lanceolate in males, but in large males of $A$. uaupesi the marginal rays are prolonged. There are usually 2 rows of teeth in the jaws, vs. usually 3 in most other species of Apistogramma, but several small species have only 2 rows of teeth, e.g., A. diplotaenia. The absence of a black blotch covering the first 1-3 spines of the dorsal fin is unusual within the genus, and a supraorbital stripe, which is a distinctive mark in most species of Apistogramma, is absent or reduced in size and pigmentation. In other species of Apistogramma, the pigmentation anteriorly on the dorsal fin may vary from deep black as in most of the species to imperceptible in, e.g., A. brevis Kullander, A. personata Kullander, and A. gibbiceps Meinken (Kullander, 1980), and the supraorbital stripe is absent or reduced in other elongate species, e.g., $A$. paucisquamis Kullander \& Staeck (1988). Small specimens show indistinct dark vertical bars, but vertical bars are typically absent in adults, which show a distinct lateral band including a distinct lateral blotch. Most other species of Apistogramma are vertically barred also as adults, and the presence of a lateral spot is variable. Species of the $A$. pertensis group are comparatively elongate, but shape variation has not been properly analyzed, and several other species, e.g., $A$. bitaeniata Pellegrin and $A$. diplotaenia, are also comparatively elongate.

We continue to recognize the A. pertensis group provisionally, including species with the combination of naked anterior chest, absence of a dark spot anteriorly in the dorsal fin, and large males with dorsal fin membranes united beyond spine tips. In large males of A. gephyra and A. pulchra, the dorsal fin lappets remain short, and we agree with Koslowski (2003) that these two species may not belong here. Apistogramma angayuara also has a low dorsal fin, but that may be explained by its small size, since united dorsal fin lappets only occur in specimens over $30 \mathrm{~mm} \mathrm{SL}$ in the other species of the A. pertensis group. In the absence of a phylogenetic analysis, the $A$. pertensis group serves as a convenient ad hoc reference for comparing similar-looking species, but it may turn out to be polyphyletic.

Within the $A$. pertensis group, A. angayuara is distinguished by the prominent abdominal stripes, i.e., three horizontal rows of dark brown spots along the sides of the abdo- men, as intense as or more intense than the lateral band. It differs from A. meinkeni, A. velifera, and A. pertensis in the presence of $2 v s .3$ post-lachrymal infraorbital pores, and from A. gephyra, A. meinkeni, and A. pulchra in the possession of 5 vs. 4 dentary pores, sharing the combination of 2 postlachrymal infraorbital pores and 5 dentary pores (Fig. 3) only with $A$. iniridae (but see below), A. uaupesi, and $A$. inornata. Apistogramma iniridae and A. uaupesi are distinguished from other species in the A. pertensis group, including $A$. angayuara, by the absence of a distinct caudal spot.

The number of openings to the lateralis canal on the head is usually constant in species of Apistogramma. A species may have either 2 or 3 postlachrymal openings (apparently the middle or the posterior opening is absent in the reduced state) and either 4 or 5 dentary openings (apparently the next to posteriormost opening is absent in the reduced state), and abnormal specimens are rare. In addition, the anguloarticular canal is absent in a few small species. Within A. iniridae $(\mathrm{N}=34)$, there is a low frequency of three instead of two postlachrymal infraorbital pores, with the two posterior pores closely approximated ( 3 in 5 specimens, 2 in 28 , canal and pores absent in 1), and a bimodal frequency of 4 (18 specimens) or 5 (16 specimens) openings to the dentary canal.

Apistogramma pertensis occurs in the middle and lower rio Negro, lower rio Tefé and rio Preto da Eva, all black-water habitats. Numerous collections from the lower rio Tapajós and from the rio Trombetas upstream to the cachoeira Porteira are tentatively assigned to A. pertensis. Apistogramma pertensis is highly sexually dimorphic, males growing much larger (38.8 $\mathrm{mm} \mathrm{SL}$ ) than females (29.9 $\mathrm{mm} \mathrm{SL}$ ) and developing a high dorsal fin with interradial membranes united beyond the spine tips, and a prolonged pelvic fin (Kullander, 1980). Apistogramma pertensis also has an inverse sexual dichromatism compared to A. angayuara because the stripes crossing the unpaired fins are more distinct in females than in males. The caudal spot varies in shape between geographical samples of $A$. pertensis. Usually the caudal spot is large and rounded or vertically ovate, extending across most of the caudal fin base. In some populations, including those from the lower rio Trombetas, however, the spot approaches a rectangular shape and is limited to the central part of the caudal fin base, resembling the spot in $A$. angayuara.

Although A. pertensis frequently shows concentrations of dark pigment at the scale margins, such a pattern is developed over most of the flanks, and does not develop into prominent stripes or spot rows along the sides of the abdomen as in $A$. angayuara. Apistogramma inornata may display two indistinct abdominal stripes and $A$. velifera possesses 3-4 distinct abdominal stripes composed of rows of small dark dots. Other species of the $A$. pertensis group possess plain abdominal sides with the exception of $A$. iniridae, which displays a series of large dark blotches immediately below the lateral band.

The absence of pronounced sexual differences in color pattern or fin shape in A. angayuara is remarkable. It is possible that the available males are not fully grown and thus do not display a full typical set of secondary male characters 


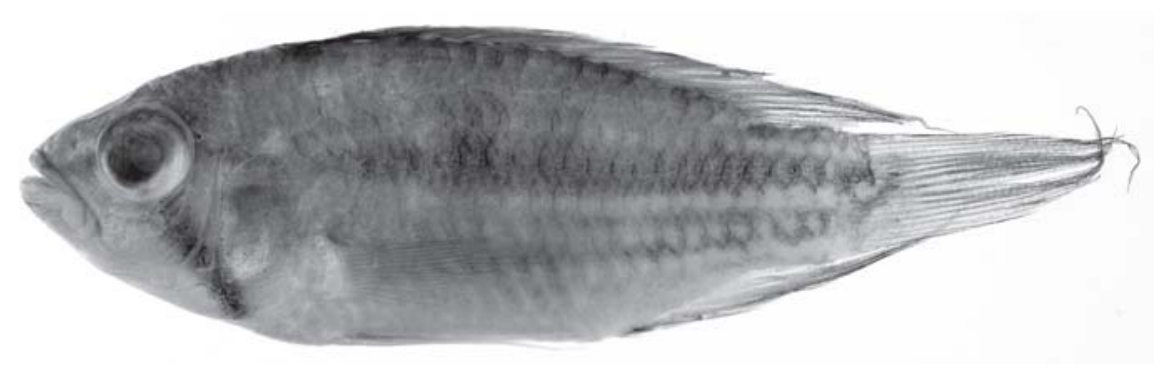

Fig. 5. Apistogramma salpinction, holotype, INPA 24507, adult male, $35.5 \mathrm{~mm}$ SL. Brazil, rio Trombetas drainage, swamp at Km 70 on margin of BR-163.

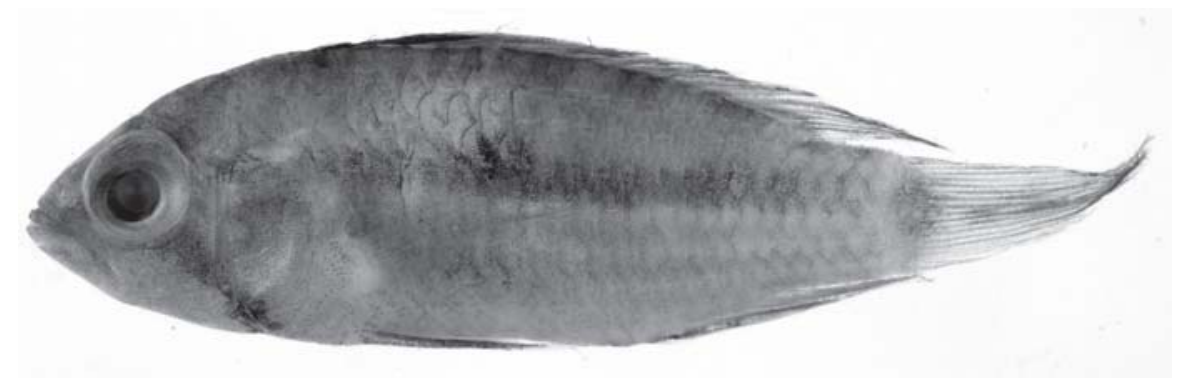

Fig. 6. Apistogramma salpinction, paratype, NRM 37027, female, $25.1 \mathrm{~mm}$ SL. Brazil, rio Trombetas drainage, swamp at Km 70 on margin of BR-163.

found in other species of the A. pertensis group such as long pelvic fin and high dorsal fin. On the other hand, gonads of several specimens examined are fully ripe and the larger specimens, both males and females, are obviously in breeding condition. With the largest specimen, a male, $24.7 \mathrm{~mm} \mathrm{SL}, A$. anguayara is the smallest species so far reported in the genus.

\section{Apistogramma salpinction, new species Figs. 4-8}

Holotype. INPA 24507. Adult male, $35.5 \mathrm{~mm}$ SL. Brazil, Estado do Pará, rio Trombetas drainage, swamp at $\mathrm{Km} 70$ on margin of BR-163. 15 Oct 1985. E. Ferreira.

Paratypes. INPA 12649 (3) and NRM 37027(3), 3 males, 23.3$29.8 \mathrm{~mm} \mathrm{SL}, 3$ females, $23.0-26.0 \mathrm{~mm} \mathrm{SL}$, collected with the holotype.

Diagnosis. A deep bodied (body depth 32.2-38.2\% of SL) species reaching at least $35 \mathrm{~mm}$ SL. Most similar to species of the $A$. cacatuoides species group in having five dentary and two postlachrymal infraorbital lateralis canal pores, and produced anterior dorsal fin membranes and marginal caudal fin rays in males. Distinguished from all other species of Apistogramma by the color pattern, which includes a lateral band and abdominal stripes which are darker and have much lighter interspaces on the caudal peduncle, and which are extended onto the caudal fin base by a caudal spot divided into elongated blotches continuing the lateral band and upper two abdominal stripes, respectively.
Description. Based on holotype with comments on variation in paratypes. See Table 2 for summary of morphometric data, and Figs. 5-6 for general aspect.

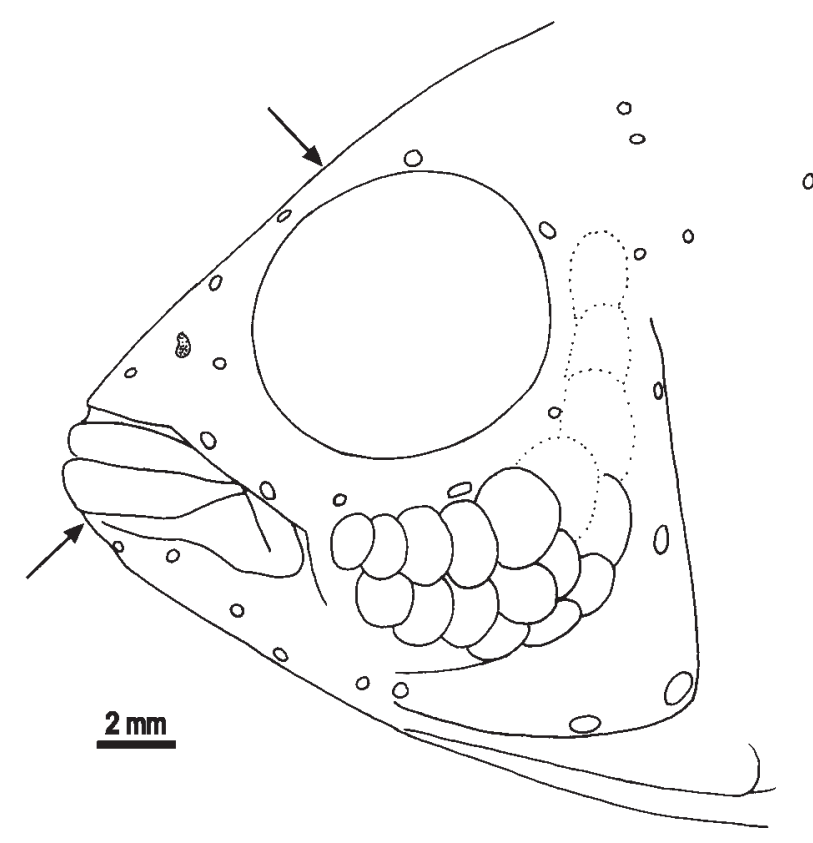

Fig. 7. Apistogramma salpinction, paratype, NRM 37027, 25.1 $\mathrm{mm} \mathrm{SL}$, pattern of lateralis openings on head. Arrows point to coronalis pore and anterior dentary pores hidden from view. 
Table 2. Morphometry of Apistogramma salpinction. Measurements expressed as percent of SL, except SL in mm; $n=7$ (4 males, 3 females). Holotype male.

\begin{tabular}{lccccc}
\hline & Holotype & Min & Max & Mean & SD \\
\hline SL (mm) & 33.5 & 23.0 & 33.5 & 26.3 & \\
Head length & 33.7 & 31.9 & 34.2 & 33.0 & 0.85 \\
Snout length & 7.2 & 5.2 & 7.2 & 5.9 & 0.62 \\
Upper jaw length & 12.8 & 9.6 & 12.8 & 10.5 & 1.09 \\
Lower jaw length & 16.1 & 13.9 & 16.1 & 14.9 & 0.75 \\
Body depth & 38.2 & 32.2 & 38.2 & 35.0 & 2.18 \\
Orbital diameter & 13.1 & 12.8 & 13.5 & 13.1 & 0.32 \\
Head width & 17.9 & 17.1 & 18.1 & 17.7 & 0.35 \\
Interorbital width & 9.0 & 7.6 & 9.0 & 8.4 & 0.53 \\
Preorbital depth & 3.3 & 2.3 & 3.3 & 2.9 & 0.33 \\
Caudal peduncle depth & 18.2 & 15.5 & 18.2 & 16.5 & 0.96 \\
Caudal peduncle length & 12.8 & 11.6 & 13.9 & 12.8 & 0.67 \\
Pectoral fin length & 30.1 & 26.9 & 33.3 & 30.0 & 2.30 \\
Pelvic fin length & 39.1 & 26.1 & 39.1 & 31.6 & 4.25 \\
Last dorsal spine length & 20.0 & 16.5 & 20.0 & 18.1 & 1.18 \\
\hline
\end{tabular}

Moderately deep (body depth 32.2-38.2 \% SL). Predorsal and prepelvic contours about equally steep. Snout short, rounded. Maxilla extending to vertical from slightly posterior to anterior margin of orbit. Eye supralateral, its dorsal margin slightly distant from the predorsal contour. Preopercle serrated in $23.0 \mathrm{~mm}$ specimen; otherwise preopercle, supracleithrum and posttemporal smooth margined.

E1 row scales 22 (6), 23 (1). Cheek completely scaled, or naked only in anteroventral corner, with 3(7) horizontal scale rows. Predorsal scales 9-10. Prepelvic area scaled, with three scales anterior to tips of cleithra; prepelvic scales 9-10. Scales in transverse row, $9 \frac{1}{2}$, of which $7 \frac{1}{2}$ below upper lateral line. Circumpeduncular scale rows 16. Lateral line scales 14/5 (1), 14/7 (2) 15/6 (1), 15/7 (2), 16/6 (1), of which 12-15/3-5 tubed. Scales between upper lateral line and dorsal fin 2-2 $1 / 2$ anteriorly, $1 / 2$ posteriorly. Fins naked except caudal fin, which is scaled on basal $1 / 4$.

Lateral line canal system on the head (Fig. 7) only examined in alcohol preserved specimens but obviously a full set of canals and foramina present, although with 2 instead of 3 postlachrymal infraorbital pores. Dentary with 5 pores; anguloarticular canal present, with anterior and posterior openings and corresponding skin pore, posterior pore separate from anteriormost preopercular; 6 preopercular pores; coronalis pore present; nasal with pores at each end, posterior obviously shared with frontal canal; frontal with 4 pores; lachrymal bone with 4 pores, posterior sharing anterior opening with first infraorbital; second infraorbital with anterior pore shared with first, and posterior pore close to caudal end of bone.

Dorsal fin in holotype with anterior lappets all relatively long, those of 4th to 6th spines appearing longest, corresponding in length to half or less than half length of corresponding spine; from 7 th immediately relatively much shorter but extending well beyond tips of their spines. In $29.8 \mathrm{~mm}$ male lappets of 4th through 8th spines prolonged, but less than half length of corresponding spines, posterior lappets gradually relatively shorter. In smaller males, 23.3 and 23.7

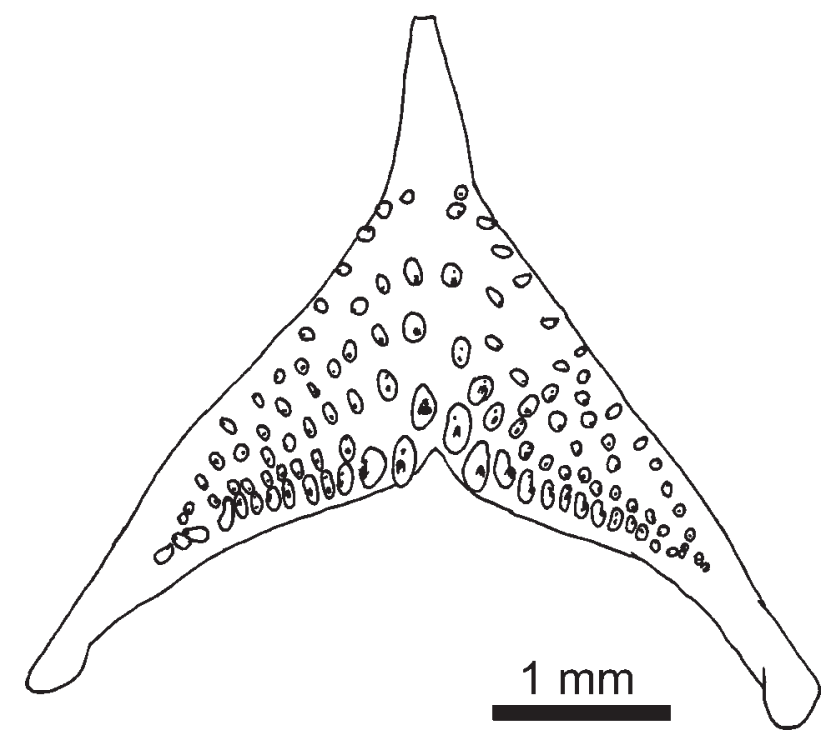

Fig. 8. Apistogramma salpinction, paratype, NRM 37027, 23.3 $\mathrm{mm} \mathrm{SL}$, lower pharyngeal toothplate in occlusal aspect.

$\mathrm{mm}$ no obvious lengthening of dorsal fin lappets; in females lappets short, rounded or truncate. Soft dorsal fin in two larger males pointed, with second ray extending to middle of caudal fin; in females pointed, but extending only slightly beyond caudal fin base; D. XIV.7 (1), XV.7 (5), XVI.6 (1). Soft anal fin pointed, in males with 3rd ray prolonged extending to beyond middle of caudal fin, in females reaching only to slightly beyond caudal fin base; A. III.4 (1), III.6 (5), III.7 (1). Caudal fin damaged in all specimens, chiefly from desiccation of distal portion. In holotype two middle caudal fin rays obviously shortest, length increasing to rays D4-5 dorsally and rays D4-5 ventrally, those rays much prolonged, forming long points nearly half length of rest of caudal fin. In smaller male $29.8 \mathrm{~mm}$ lower and middle rays damaged by a bite, in males 23.3 and $23.7 \mathrm{~mm}$ rays D4-5 apparently slightly longer than rest, but lower lobe damaged. In female $25.1 \mathrm{~mm}$ middle appearing truncate, and rays D4-5 and V4 are slightly prolonged; in female $26.0 \mathrm{~mm}$ ray V5 may be longer than remaining, and in female $23.0 \mathrm{~mm}$ caudal fin appearing truncate without prolonged rays. Caudal fin with 3 procurrent and 8 principal rays in each lobe. Pelvic fin pointed, first ray produced in males, extending to at most (in holotype) third anal spine; in females pointed, extending to vent. Pectoral fin rounded, extending almost to vertical from vent; P. 11 (3), 12 (4).

Jaw teeth caniniform, erect, strongly linguad curved; 2128/22-25 in upper/lower jaw outer hemiseries. Outer row teeth slightly larger or subequal in size to inner row teeth. Outer row extending along entire jaw margin; inner row in upper jaw extending as far as outer row in holotype, but only to middle of jaw in paratypes, a few teeth anteriorly forming short middle row in two specimens; two inner rows in lower jaw, one symphysially, one extending to middle of jaw. 
Gill rakers externally on first gill arch, one in angle and 1 (5), 2 (1), 3 (1) ceratobranchial gill rakers; gill rakers on lower pharyngeal tooth-plate 10 (2), 11 (2), 12 (1), 13 (1), 14 (1). Lower pharyngeal tooth-plate (Fig. 8) slightly wider than long (length $77 \%$ of width), deeply emarginate posteriorly; $16+14$ teeth in posterior row, 4 teeth in median row. Medioposterior teeth largest, teeth gradually decreasing in length rostrad and laterad; medioposterior teeth and teeth in two posterior transverse rows bicuspid, lateral and rostral teeth slender and unicuspid.

Vertebrae $12+12=24(6), 12+13=25$ (1). Hypurals $1-5$ separate in 6 specimens; hypurals $3+4$ fused in one specimen.

Color pattern in alcohol. All specimens are slightly discolored, but pattern of dark markings appearing only marginally affected. Ground color yellowish-whitish; top of head and dorsum brownish, sides lighter. No vertical bars. Sides with lateral band and abdominal stripes, which are indistinct anteriorly on side, more intensely pigmented posteriorly, particularly on caudal peduncle, where light interspaces are also more contrasted. Wide brownish lateral band from gill cleft to end of caudal peduncle, more intensely pigmented posteriorly, but then with lighter scale centers; running in E1 row and extending onto adjacent $1 / 4$ of row 0 and E2 scales; a light zone bordering band dorsally on caudal peduncle. Along middle of row 0 scales a light to white stripe present, which fades anteriorly on side. Along middle of E2 scales a white stripe present on caudal peduncle only. Overlapping $1 / 4$ of row 0 and $\mathrm{H} 1$ row scales, and of $\mathrm{H} 1$ and $\mathrm{H} 2$ row scales, indistinctly on overlapping $1 / 4$ of $\mathrm{H} 2$ and $\mathrm{H} 3$ row scales, are brown abdominal stripes, of which upper two joined by dark margins of $\mathrm{H} 1$ row scales on caudal peduncle.

Lateral spot as a trace or only slightly darker than lateral band, rounded, covering E1 scales 5-7 or 6-7 and parts of scales above.

Indistinct dark brown pigment patch representing supraorbital stripe close to orbital margin. Preorbital stripe brownish. Postorbital stripe brown, from orbit to lateral band. Dark brown suborbital stripe, of about same width as pupil diameter, extending caudoventrad, distally slightly ventrad curved, from between anterior pores of second infraorbital bone across lower portion of vertical limb of preopercle and onto opercle, preopercle and subopercle in the region where those bones meet. Dark brown spot at mandibular tip, immediately posterior to lower lip fold. Snout grayish. Dark brown spot dorsally at base of pectoral fin.

Dorsal fin anterior two or three membranes dark brown to blackish, rest of fin smoky with slightly darker lappets and a dark brown spot at base of each spine and ray, particularly intense and forming a nearly continuous blotch over bases of anterior soft rays, rest of fin immaculate. Anal fin with wide brown lower margin, otherwise brownish, inwardly hyaline, immaculate. Caudal spot in smaller specimens midbasal, dark brown, rounded; in larger specimens with whitish middle portion and intensified to form extensions of lateral band and upper two abdominal stripes; rest of fin dusky, with indicated vertical bars only in two small specimens; in two largest males and in females, a hyaline submarginal stripe dorsally, covering approximately rays D5-6 and interradial membrane. Pelvic fin in males with sparse black pigmentation on inner part of lateral aspect, rest of fin hyaline.

Females different from males in having anterior half of lateral side of pelvic fin black; quite some pigmentation on chest but no blotch, and an intense black midventral stripe extending back to anal fin.

Geographical distribution Known only from the type locality (Fig. 4), a very large swamp at $\mathrm{Km} 70$ on the margin of BR163.

Ecology and habitat. The type locality is a large swamp, with mud bottom. At the time of sampling it was very shallow, in some places not more than $5 \mathrm{~cm}$ deep. The swamp probably has a connection to the igarapé Caxipacoré during the high water season, and during the dry season it dries out.

Etymology. Salpinctes $(\sigma \alpha \lambda \pi \imath \gamma \tau \eta \varphi)$, Greek noun meaning trumpeter, with the diminutive suffix -ion; in allusion to the type locality drainage, the Trombetas (Portuguese for trumpets), and the small body size. To be treated as a noun in apposition.

Relationships. Apistogramma salpinction is similar to species of the A. cacatuoides species group (A. cacatuoides Hoedeman, A. juruensis Kullander, and A. luelingi Kullander), also showing pronounced sexual dimorphism, including produced dorsal fin lappets and long caudal fin streamers in males, and two postlachrymal infraorbital pores. The slightly ventrad curved distal portion of the suborbital stripe and the relatively inconspicuous midlateral spot are also shared.

Apistogramma salpinction is similar to A. cacatuoides, A. juruensis and A. luelingi in possessing well developed abdominal stripes, but unlike in those species, there is no obvious sexual dimorphism in the appearance of the stripes, considered a synapomorphy of the A. cacatuoides species group by Kullander (1986) and Kullander \& Staeck (1988), and also instead of being most intense on the sides of the abdomen, the stripes of $A$. salpinction become most intense on the caudal peduncle.

Other species of the A. cacatuoides species group possess spotted soft unpaired fins, whereas those fins are immaculate in A. salpinction. Males of A. luelingi and $A$. cacatuoides usually present hyaline spots situated dorsally in the caudal fin and across rays, but in A. salpinction there is a submarginal hyaline stripe parallel to rays and present in both sexes.

Apistogramma arua, from the rio Arapiuns, may also belong to the A. cacatuoides group. Males possess prolonged anterior dorsal fin lappets and dorsal and ventral streamers in the caudal fin and relatively large mouths, similar to $A$. cacatuoides, A. luelingi, and A. juruensis. The color pattern of the sides of the abdomen is different from that of both $A$. 
salpinction and other species of the A. cacatuoides group, including a blackish or brown area anteriorly on the side behind the pectoral fin base and partially confluent vertical bars of the same color extending down from the lateral band, leaving contrasting whitish spaces as light blotches along the lateral band, and there is no sexual dimorphism in the abdominal color pattern.

A truncate to slightly emarginate caudal fin shape in females has been noted for A. luelingi, A cacatuoides, A. bitaeniata (Kullander, 1986: 171, 181 193) and A. martini Römer et al. (Koslowski, 2002: 243, A. sp. "Leierschwanz"), but except in the last-mentioned species the marginal streamers are much shorter than in males. The development of caudal fin streamers and elongated lappets may to some extent be size related in Apistogramma, as those characters are best developed in large males well past the maximum size of females.

\section{Discussion}

There is relatively little information about the natural diet of species of Apistogramma. Goulding et al. (1988: 135, $137,139)$ reported detritus in $A$. pertensis and $A$. sp. from the rio Urubaxi, autochthonous invertebrates in $A$. regani Kullander from Anavilhanas, detritus and autochthonous invertebrates in A. pertensis from ilha Buiu-Açu, and detritus in A. pertensis from ilha Tamaquaré. Bergleiter (1999) reported a mixed diet but mainly cladocerans, copepods, chironomid larvae and other aquatic insect larvae in stomachs of $A$. gephyra from the rio Xingu. Marlier (1968) reported chiefly ostracods, copepods, cladocerans and aquatic insect larvae from $A$. taeniata (Günther) (probably $A$. regani) in lago Redondo. Knöppel (1970) found significant amounts of plant matter, detritus, fruits and water mites along with insect larvae, in $A$. agassizii from lago Calado. In a tributary to the rio Puraquequara, Silva (1993) reported mainly autochthonous insect larvae in $A$. agassizii (Steindachner) and A. regani, but only detritus in two specimens of an unidentified species. Although largely anecdotal from an autecological perspective the information on stomach contents from several species of Apistogramma thus points to substrate feeding with detritus and plant matter ingested along with dominating small crustaceans and insect larvae.

Apistogramma angayuara from rapids also had eaten mainly aquatic invertebrates but the dominant item is protozoans (rhizopods). The rhizopods were not identified to species, but rhizopods generally are substrate living and may be assumed to have been selected from substrate vegetation. Since no plant matter was found in the stomachs, the rhizopods are unlikely to have been taken accidentally with plants or algae. We have not found any report on other fishes specialized in protozoans, and this feeding niche should be investigated further among substrate feeding Amazonian fishes of small size.

Previous records of species of Apistogramma from the rio Trombetas refer to $A$. geisleri, described from near the mouth region, and $A$. agassizii from Óbidos (Kullander, 1980).
We refer several samples from the rio Trombetas up to the cachoeira Porteira to $A$. pertensis. From the cachoeira Vira Mundo upstream we have recorded $A$. anguayara, $A$. salpinction and a species similar to $A$. hippolytae. Several other cichlid species are known only from the cachoeira Porteira and/or a short distance upstream in the Trombetas, viz. Aequidens tubicen Kullander \& Ferreira (1991), Crenicichla heckeli Ploeg (1991), C. pydanielae Ploeg (1991), and C. tigrina Ploeg et al. (1991). No cichlid species is known to occur both upstream and downstream of the cachoeira Porteira. Species of other families so far known only from the cachoeira Porteira and upstream in the Trombetas and/or Mapuera include the characid Bryconexodon trombetasi Jégu et al. (1991), from rapids and fast running water, the anostomid Sartor elongatus Santos \& Jégu (1987), and the loricariid Harttia trombetensis Py-Daniel \& Oliveira (2001). The serrasalmid Mylesinus paraschomburgkii Jégu et al. occurs in the cachoeira Porteira and rapids upstream, but also in upstream localities in the rio Uatumã which is located to the west of the rio Trombetas drainage (Jégu et al., 1989).

Ploeg (1989) described C. regani from the cachoeira Porteira, but reported the species from numerous other localities in the Amazon basin (Ploeg 1989, 1991). We tentatively consider Ploeg's material of C. regani to consist of several similar species in need of revision.

It thus seems likely that the lower rapids of the Trombetas form a distribution barrier to species of Apistogramma, Aequidens, and Crenicichla. Other cichlid species from the Trombetas still under study support this interpretation. Since the available collections are restricted to the cachoeira Porteira and short distances upstream in the rio Trombetas and rio Mapuera, it is not possible to speculate on the general distribution of these taxa further upstream in the rio Trombetas drainage. Cichlid distributions in the better known southern Amazon tributaries, the Tapajós, Xingu, and Tocantins, which are also separated from the Amazon by rapids, show that species occurring in and above the lower rapids generally are endemic and found in the entire drainage or at least in several localities in each drainage (e.g., Kullander, 1991b, 2003; pers. obs.). On the other hand, many of these species are associated with the rapids and may signal rheophilic stenotopy more than rapids as dispersal barriers, e.g., C. urosema Kullander (1990), C. phaiospilus Kullander (1991a) and $C$. percna Kullander (1991a), Geophagus argyrostictus Kullander (1991b), and species of Retroculus (Gosse, 1971) and Teleocichla (Kullander, 1988; Zuanon \& Sazima, 2002). Of the endemic cichlid species from the rio Trombetas, $C$. heckeli, $C$. tigrina, and $A$. angayuara appear to be associated with rapids, whereas Aequidens tubicen, C. pydanielae, and Apistogramma salpinction were collected in lentic habitats.

\section{Acknowledgements}

This paper was conceived and drafted in the late 1980s and then with financial support from the Swedish Natural 
Science Research Council, grant B-BU 4568 to SOK. Collecting in the rio Trombetas was made possible through financial support from Projeto Ictiofauna - Cachoeira Porteira (Convênio INPA/CNPq/Eletronorte) to EJGF. We thank Ingo Koslowski and two anonymous reviewers for constructive criticism of the manuscript.

\section{Literature cited}

Bergleiter, S. 1999. Zur ökologischen Struktur einer zentralamazonischen FischZönose. Ethologische und morphologische Befunde zur Ressourceinteilung. Zoologica, 149:191 pp.

Ferreira, E. J. G. 1993. Composição, distribuição e aspectos ecológicos da ictiofauna de um trecho do rio Trombetas, na área de influência da futura UHE cachoeira Porteira, Estado do Pará, Brasil. Acta Amazonica, 23 (1\4, suplemento):1-89.

Gosse, J. P. 1971. Révision du genre Retroculus (Castelnau, 1855), designation d'un neotype de Retroculus lapidifer (Castelnau, 1855) et description de deux espèces nouvelles. Bulletin Institut royal des Sciences natuelles de Belgique, $47(43): 1-13$.

Goulding, M., M. L. Carvalho \& E. G. Ferreira. 1988. Rio Negro. Rich life in poor water. The Hague, 200 pp.

Grenand, F. \& E. H. Ferreira. 1989. Pequeno dicionario da Lingua Geral. SEDUC/Núcleo de Recursos Tecnologicos, Manaus.

Jégu, M., G. M. dos Santos \& E. Ferreira. 1989. Une nouvelle espèce du genre Mylesinus (Pisces, Serrasalmidae), $M$. paraschomburgkii, décrite des bassins du Trombetas et du Uatumã (Brésil, Amazonie). Revue d'Hydrobiologie Tropicale, 22:49-62.

Jégu, M., G. M. dos Santos \& E. Ferreira. 1991. Une nouvelle espèce de Bryconexodon décrite du bassin du Trombetas (Parà, Brésil). Journal of Natural History, 25:773-782.

Knöppel, H.-A . 1970. Food of central Amazonian fishes. Contribution to the nutrient-ecology of Amazonian rain-forest-streams. Amazoniana, 2:257-352.

Koslowski, I. 2002. Die Buntbarsche Amerikas. Band 2: Apistogramma \& Co. Verlag Eugen Ulmer, Stuttgart, 318pp.

Kullander, S. O. 1980. A taxonomical study of the genus Apistogramma Regan, with a revision of Brazilian and Peruvian species. Bonner zoologische Monographien, 14:1-152.

Kullander, S. O. 1986. Cichlid fishes of the Amazon River drainage of Peru. Swedish Museum of Natural History, Stockholm, $431 \mathrm{pp}$.

Kullander, S. O. 1987. A new Apistogramma species from the Rio Negro in Brazil and Venezuela. Zoologica Scripta, 16:259-270.

Kullander, S. O. 1988. Teleocichla, a new genus of South American rheophilic cichlid fishes with six new species. Copeia, 1988:196-230.

Kullander, S. O. 1990. A new species of Crenicichla from the Rio Tapajós, Brazil, with comments on interrelationships of small crenicichline cichlids. Ichthyological Exploration of Freshwaters, 1:85-94.

Kullander, S. O. 1991 a. Crenicichla phaiospilus and $C$. percna, two new species of pike cichlids from the Rio Xingu, Brazil. Ichthyological Exploration of Freshwaters, 1:351-360.

Kullander, S. O. 1991 b. Geophagus argyrostictus, a new species of cichlid fish from the Rio Xingu, Brazil. Cybium, 15:129-138.

Kullander, S. O. 2003. Family Cichlidae. Pp. 611-660. In Reis, R. E., S. O. Kullander \& C. J. Ferraris (eds.). Check list of the freshwater fishes of South and Central America. Edipucrs, Porto Alegre.

Kullander, S. O. \& E. J. G. Ferreira. 1991. A new Aequidens species from the Rio Trombetas, Brasil, and redescription of Aequidens pallidus. Zoologica Scripta, 19:425-433.

Kullander, S. O. \& W. Staeck. 1988. Description of a new Apistogramma species from the Rio Negro in Brazil. Cybium, 12: 189-201.

Marlier, G. 1968. Études sure les lacs de l'Amazonie Centrale. II. Le plancton. III. Les poissons du lac Redondo et leur régime alimentaire* les chaines trophiques du lac Redondo* les poissons du Rio Preto da Eva. Cadernos da Amazônia, 11:1-57.

Ploeg, A. 1989. Zwei neue Arten der Gattung Crenicichla Heckel, 1840 aus dem Amazonasbecken, Brasilien (Pisces, Perciformes, Cichlidae). Aquarien- und Terrarienzeitschrift, 42:163-167.

Ploeg, A. 1991. Revision of the South American cichlid genus Crenicichla Heckel, 1840, with descriptions of fifteen new species and considerations on species groups, phylogeny and biogeography. Academisch Proefschrift, Universiteit van Amsterdam, $153 \mathrm{pp}$.

Ploeg, A., M. Jégu \& E. Ferreira. 1991. Crenicichla tigrina, une nouvelle espèce de Cichlidae du Rio Trombetas, Pará, Brésil. Bulletin Zoölogisch Museum Universiteit van Amsterdam, 13:1-11.

Py-Daniel, L. H. and E.C. Oliveira. 2001. Seven new species of Harttia from the Amazonian-Guyana region (Siluriformes: Loricariidae). Ichthyological Exploration of Freshwaters, 12:79-96.

Santos, G. M. \& M. Jégu. 1987. Novas occorências de Gnathodolus bidens, Synaptolaemus cingulatus e descrição de duas espécies novas de Sartor. Amazoniana, 10:181-196.

Silva, C. P. D. 1993. Alimentação e distribuição de algumas espécies de peixes do igarapé do Candirú, Amazonas, Brasil. Acta Amazonica, 23:271-285.

Staeck, W. 2003. Cichliden-Lexikon Teil 3. Südamerikanische Zwergbuntbarsche. Dähne Verlag, Ettlingen, 219 pp.

Zuanon, J. \& I. Sazima. 2002. Teleocichla centisquama, a new species of rapids-dwelling cichlid from Xingu River, Amazonia (Perciformes: Cichlidae). Ichthyological Exploration of Freshwaters, 13:373-378.

Received February 2005 Accepted July 2005 